Шкромада О. І., кандидат ветеринарних наук

Сумський національний аграрний університет

\title{
ТОКСИЧНИЙ ВПЛИВ ОКСИДІВ МЕТАЛІВ НА ОРГАНІЗМ ТВАРИН
}

\section{Рецензент - доктор ветеринарних наук М. І. Харенко}

Стаття присвячена вивченню безпеки й одночасно ефективності використання нанопорошків оксидів металів: діоксид титану, червоний залізоокисний пітмент та сульфат міді. Проведення токсикологічних досліджень показало, щчо оксиди металів $\left(\mathrm{Fe}_{2} \mathrm{O}_{3} \mathrm{i} \mathrm{TiO} \mathrm{T}_{2}\right)$ проявляють бактерицидну активність у концентрації 0,2-2 мг/л. Вони мають досить низьку цитотоксичність і летальність. Нанопорошок міді характеризується $60 \%$ токсичністю в дозі 50 мг/кг і максимально вираженою токсичністю у діапазоні 125-500 ма/кг.

Ключові слова: нанопорошки оксидів металів, циитотоксичність, бактерищидні властивості, безпека.

Постановка проблеми. Останнім часом нанотехнологія та ії здобутки поряд із іншими науками (біологія, гуманна медицина та ін.) інтенсивно вивчаються у ветеринарній медицині. В Україні широко застосовуються нанопорошки окремих металів в якості дезінфектантів. Виникла необхідність дослідити їх безпеку для тварин i водночас бактерицидні властивості.

Аналіз основних досліджень і публікацій, у яких започатковано розв'язання проблеми. Для того, щоб зменшити кількість мікроорганізмів у повітрі й на огороджуючих конструкціях сільськогосподарських приміщень, використовують дезінфектанти. В основному, вони $є$ досить токсичними сполуками (луги або кислоти), які викликають руйнацію поверхневого шару будівельних матеріалів. Тому ми звернулися до препаратів, які не токсичні для людей і тварин, викликають загибель мікроорганізмів і не руйнують оброблені поверхні. Такими препаратами $\epsilon$ діоксид титану (рутил і анатаз), червоний залізоокисний пігмент $[3,4]$.

$\mathrm{TiO}_{2}$ - діоксид титану - синтетичний неорганічний пігмент білого кольору, який отримують гідролізом розчинів сірчанокислого титану із наступним пропалюванням гідратованої двоокису титану. Для досліджень використовували титану діоксид пігментний марок SumTITAN R-206 TУ У 24.1-05766356-054:2005. Пігментна двоокис титану не має токсичних подразнюючих властивостей, не виділяє у навколишнє середо- вище токсичних речовин і не впливає при безпосередньому контактуванні на організм людини. Він хімічно стійкий, має хороші оптичні властивості, що призводить до високої укривістості, білизні композиційних матеріалів і покрить.

Червоний залізоокисний пігмент широко використовується у лакофарбовій, паперовій, будівельній та інших галузях промисловості. Його часто використовують разом із діоксидом титану для зменшення білизни. Оксид заліза має властивість згущувати розчини, тому що його часточки мають велику масу і можуть викликати зсув $\mathrm{pH}$ у лужний бік $[1,2]$.

Сульфат міді використовується у будівництві, для обробки деревини, має прекрасні фунгіцидні властивості.

Речовини у вигляді нанопорошків перебувають у метастабільному стані й тому мають підвищену хімічну активність, що зумовлена як розмірами, так і структурою (пласка, полігональна, куляста форма тощо). Ширина переважної більшості наночасток заліза і нанотитану становить 111,6 нм, а товщина - 4,9 нм. Нанопорошки активно взаємодіють із біологічними рідинами у залежності від $\mathrm{pH}$ середовища та компонентного складу дають відповідні продукти. Дія нанопорошків на організм проявляється передусім наявністю наночасток сторонніх тіл (для індиферентних часток) на клітинному і макромолекулярному рівнях, а також токсичним впливом продуктів взаємодії наночасток із біологічними рідинами (субстанціями) [5-7].

Мета дослідження - визначити загальну токсичну дію нанопорошків оксидів металів у вигляді суспензій на організм лабораторних мишей, їх цитотоксичну активність на клітинному $\mathrm{i}$ молекулярному рівні.

Матеріал і методи досліджень. Експерименти in vivo проводилися на лабораторних мишах. Нанопорошок заліза, нанотитану рутилу та анатазу диспергували в ізотонічному розчині $\mathrm{NaCl}$. Суспензія мала величину дисперсної фази 5 г/л. Певний об'єм суспензії вводили в черевну порожнину, при цьому доза нанопорошку становила від 25 до 500 мг/кг живої маси. Критерієм ток- 
сичності слугувала доза $\mathrm{LD}_{100}$. Результати дослідження токсичної дії нанопорошків $\mathrm{Fe}_{2} \mathrm{O}_{3}, \mathrm{TiO}_{2}$, $\mathrm{CuSO}_{4}$ на мишах (по 5 тварин у кожній групі) наведені в табл. 1.

Цитотоксичність нанометричних порошків оксидів металів вивчали на культурі клітин нирки теляти, вираховуючи відсоток загибелі клітин під час обробки клітинної культури наносуспензією.

Біологічну активність нанопорошків оксидів металів визначали за активністю ферменту алкогольдегідрогенази дріжджів у процесі зменшення концентрації в часі в розчині глюкози і в розчині пірувату натрію в середовищі Рідера, а також у пивному суслі.

Антибактеріальну активність суспензії порошків металів встановлювали в діапазоні доз 0,02-2,0 мг/мл стосовно кишкової палички, стафілокока і протея.

Результати дослідження. Токсична дія нанопорошків оксидів металів на тваринний організм у діапазоні доз 25-500 мг/кг для кожного металу була різною (табл. 1). Суспензію оксидів металів вводили мишкам внутрішньочеревенно.

Як видно з даних табл. 1, нанометричний порошок оксиду заліза і титану не викликав загибелі жодної миші в діапазонах доз 25-500 мг/кг, що засвідчує цілковиту його нешкідливість. Найбільш токсичним виявився нанопорошок сульфату міді, який у дозі 50 мг/кг призвів до загибелі 60 \% піддослідних, а в більших дозах і стовідсоткового летального кінця.

Отже, нанопорошки оксидів заліза і титану на рівні тваринного організму не токсичні, порівняно із нанопорошоком міді. Ступінь цитотоксичності нанопорошків металів наведено в табл. 2.

Як видно $з$ даних табл. 2, нанопорошки оксиду заліза і титану майже не викликають ознак цитотоксичності, частка загиблих клітин знаходиться в межах природної культуральної втрати. Нанопорошок міді має виражену цитотоксичність.

\section{1. Токсичність нанопорочків оксиду металів}

\begin{tabular}{|c|c|c|c|c|c|c|}
\hline \multirow{2}{*}{$\begin{array}{c}\text { Доза нанопроршку } \\
(\text { мг/кг) }\end{array}$} & \multicolumn{2}{|c|}{$\mathrm{Fe}_{2} \mathrm{O}_{3}$} & \multicolumn{2}{c|}{$\mathrm{TiO}_{2}$} & \multicolumn{2}{c|}{ СuSO $_{4}$} \\
\cline { 2 - 7 } & $\begin{array}{c}\text { кількість } \\
\text { мишей у } \\
\text { досліді }\end{array}$ & $\begin{array}{c}\text { кількість } \\
\text { мишей, які } \\
\text { загинули }\end{array}$ & $\begin{array}{c}\text { кількість } \\
\text { мишей у } \\
\text { досліді }\end{array}$ & $\begin{array}{c}\text { кількість } \\
\text { мишей, які } \\
\text { загинули }\end{array}$ & $\begin{array}{c}\text { кількість } \\
\text { мишей у } \\
\text { досліді }\end{array}$ & $\begin{array}{c}\text { кількість } \\
\text { мишей, які } \\
\text { загинули }\end{array}$ \\
\hline 25 & 10 & 0 & 10 & 0 & 10 & 0 \\
\hline 50 & 10 & 0 & 10 & 0 & 10 & 6 \\
\hline 125 & 10 & 0 & 10 & 0 & 10 & 8 \\
\hline 250 & 10 & 0 & 10 & 0 & 10 & 10 \\
\hline 500 & 10 & 0 & 10 & 0 & 10 & 10 \\
\hline
\end{tabular}

2. Цитотоксична активність нанопорошків оксидів металів

\begin{tabular}{|c|c|c|c|}
\hline \multirow{2}{*}{ Нанопорошок } & \multirow{2}{*}{ Доза мг/л } & \multicolumn{2}{|c|}{ Кількість 3бережених життєздатних клітин, \% } \\
\cline { 2 - 4 } & 0,02 & через 48 годин & через 72 години \\
\hline \multirow{3}{*}{$\mathrm{Fe}_{2} \mathrm{O}_{3}$} & 0,2 & 99,2 & 98,2 \\
\cline { 2 - 4 } & 2 & 98,8 & 97,9 \\
\cline { 2 - 4 } & 0,02 & 97,5 & 96,6 \\
\hline \multirow{3}{*}{$\mathrm{TiO}_{2}$} & 0,2 & 99,4 & 98,5 \\
\cline { 2 - 4 } & 2 & 98,6 & 97,3 \\
\hline \multirow{3}{*}{$\mathrm{CuSO}_{4}$} & 0,02 & 97,2 & 96,3 \\
\hline & 0,2 & 78,8 & 66,2 \\
\hline & 2 & 25,8 & 20,9 \\
\hline Контроль & - & 18,5 & 16,6 \\
\hline
\end{tabular}

3. Антибактеріальна активність нанопорошків оксидів металів

\begin{tabular}{|c|c|c|c|c|c|c|c|c|c|c|c|}
\hline \multirow{2}{*}{$\begin{array}{c}\text { Нано- } \\
\text { порошок }\end{array}$} & \multicolumn{8}{|c|}{ Esherihia coli } & \multicolumn{7}{c|}{ Staphylococcus aureus } & \multicolumn{3}{c|}{ Proteus vulgaris } & \multirow{2}{*}{ Контроль } \\
\cline { 2 - 13 } & 0,02 & 0,2 & 2 & 0,02 & 0,2 & 2 & 0,02 & 0,2 & 2 & - \\
\hline $\mathrm{Fe}_{2} \mathrm{O}_{3}$ & + & - & - & + & - & - & + & - & - & + \\
\hline $\mathrm{TiO}_{2}$ & + & - & - & + & - & - & + & + & - & + \\
\hline $\mathrm{CuSO}_{4}$ & \pm & + & + & \pm & + & + & \pm & + & + & + \\
\hline
\end{tabular}


Дослідження антибактеріальної активності нанопорошків проводили 3 дозами у діапазоні 0,02-2 мг/мл до кишкової палички, стафілокока і протея (табл. 3).

Як свідчать дані таблиці 3, всі препарати мають виражену протимікробну дію, проте у сульфату міді вона менш виражена.

Перспектива досліджень. Оксиди металів $\left(\mathrm{Fe}_{2} \mathrm{O}_{3} \mathrm{i} \mathrm{TiO}_{2}\right)$ можна використовувати в якості дезінфектантів, оскільки вони проявляють бактерицидну активність. Окрім того їх можна застосовувати в присутності тварин, тому що вони

\section{БІБЛІОГРАФІЯ}

1. Головенко М. Я. Наномедицина: досягнення та перспективи розвитку новітніх технологій у діагностиці та лікуванні / М. Я. Головенко // Журнал АМН України. - 2007. - Т. 13. - №4. - С. 4-25.

2. Головенко Н. Я. Физико-химическая фармакология / Н. Я. Головенко. - Одесса: Астропринт, 2004. $-720 \mathrm{c}$.

3. Гудзь О. В. Влияние четвертичньїх аммониевых соединений на функциональное состояние цитоплазматической мембраны Escherichia coli / О. В. Гудзь, Е. Т. Писько // Микробиология. 1988. - Т. 50. - №3. - С. 75-78.

4. Гудзь О. В. Адаптационные возможности возбудителей гнойной инфекции к поверхностноактивньїм антисептическим средствам / О.В.Гудзь мають стимулювальну активність на рівні тваринного організму і характеризуються досить незначною цитотоксичністю.

\section{Висновки:}

1. Оксиди металів $\left(\mathrm{Fe}_{2} \mathrm{O}_{3} \mathrm{i} \mathrm{TiO}_{2}\right)$ проявляють бактерицидну активність у концентрації 0,2-2 мг/л.

2. Вони мають досить низьку цитотоксичність і летальність.

3. Нанопорошок міді характеризується $60 \%$ токсичністю в дозі 50 мг/кг і максимально вираженою токсичністю у діапазоні 125-500 мг/кг.

// Врачебное дело. - 1989. - №2. - С. 105-107.

5. Йоффе Б. С. Синтез і застосування катіонних ПАР. Хлорна промисловість. / Б. С. Йоффе, Е. П. Бабаян, Р. Е. Злотник. - М.: НИИТЕХИМ, 1988. $-42 \mathrm{c}$.

6. Марієвський В. Ф. Зміна чутливості мікроорганізмів до дезінфектантів в залежності від стадії росту / В. Ф. Марієвський, I. I. Даниленко, Л. В. Пархоменко // Тези XI з'їзду мікробіологів, епідеміологів та паразитологів. - К., 2004. C. 20-21.

7. Maynard A. D. Nanotechnology: A research strategy for addressing risk. / Maynard A. D. Project on Emering Nanotechnologies suportied by RHE PEW CHARITABLE TRUST, 2003. - 112 p. 